\title{
Edukasi COVID-19 Melalui Program KKN COVID UNS Meningkatkan Kesadaran Budaya Hidup Sehat di Sumber Dukuhan, Banjarsari, Surakarta
}

\author{
Pritha Marsha Elapuspita $^{1}$, Valiant Lukad Perdana Sutrisno ${ }^{2}$ \\ ${ }^{1}$ Office Administration Education The Faculty of Teacher Training and Education Sebelas Maret \\ University Indonesia \\ ${ }^{2}$ Mechanical Engineering Education The Faculty of Teacher Training and Edcuation Sebelas \\ Maret University Indonesia \\ Corresponding email: tithamarsha@gmail.com
}

\begin{abstract}
COVID-19 (Coronavirus) is a virus that attacks the body's immune system, especially in the human respiratory system. The way to prevent exposure to this virus is to always cultivate a healthy lifestyle both for yourself and the environment. One way to prevent the COVID-19 virus is to always use a mask and a hand sanitizer, which is one of the things that is often ignored and is often considered unimportant for people who think only washing hands is enough, but if washing hands is not done in a way that is not important. really will be housewife. My goal in carrying out community service activities is in addition to providing understanding as well as increasing awareness to local residents to always adopt a healthy lifestyle and always adhere to health protocols starting from small things, namely by using masks and handsanitizers to avoid the COVID-19 virus. This activity is carried out directly and indirectly. This is done indirectly by sharing information online which is aimed at closest friends and closest relatives, indirect activities are carried out by providing direct socialization to PKK mothers when paying for social gathering at the same time by providing masks and handsanitizers while being given. information about the benefits and proper and correct use of them, apart from distributing masks, MMTs and posters were also installed in several strategic places in the hamlet as a way to remind local residents to always adopt a healthy lifestyle and comply with health protocols.
\end{abstract}

Keywords: education, masks, handsanitizer, real work lecture, covid-19.

\begin{abstract}
ABSTRAK
COVID-19 (Coronavirus) merupakan virus yang menyerang imun tubuh terutama pada sistem pernapasan manusia. Cara untuk mencegah terkena virus ini yaitu dengan selalu membudayakan pola hidup sehat baik diri sendiri maupun lingkungan sekitar. Salah satu cara untuk mencegah virus COVID-19 yaitu
\end{abstract}


dengan selalu menggunakan masker dan handsanitizer adalah salah satu hal yang sering diabaikan dan sering di anggap tidak penting bagi orang-orang yang berpikiran hanya dengan mencucui tangan saja cukup tetapi jika cuci tangan tidak dilakukan dengan cara yang benar akan menjadi percumah. Tujuan saya dalam melakukan kegiatan pengabdian dimasyarakat ini adalah selain untuk memberikan pemahaman juga untuk meningkatkan kesadaran kepada warga sekitar untuk selalu menerapkan pola hidup sehat dan selalu menaati protokol kesehatan dimulai dari hal kecil yaitu dengan menggunakan masker dan handsanitizer agar terhindar dari virus COVID-19. Kegiatan ini dilakukan secara langsung dan tidak langsung. Untuk secara tidak langsung dilakukan dengan cara membagikan informasi secara online yang ditujukan untuk teman-teman terdekat dan saudarasaudara terdekat, untuk kegiatan tidak langsung dilakukn dengan memberikan sosialisasi secara langsung kepada ibu-ibu PKK ketika membayar arisan sekaligus dengan memberikan masker dan handsanitizer sembari diberikan informasi mengenai manfaat dan cara penggunaannya yang baik dan benar, selain membagikan masker juga dilakukan pemasangan mmt dan poster di beberapa tempat strategis di sumber dukuhan sebagai salah satu cara untuk meningatkan kepada warga sekitar untuk selalu menerapkan pola hidup sehat dan mematuhi protokol kesehatan.

Kata kunci: edukasi, masker, handsanitizer, kuliah kerja nyata, covid-19.

\section{PENDAHULUAN}

Coronavirs jenis baru yang ditemukan menyebabkan penyakit COVID-19 (WHO, 2020) menurut World Health Organization (WHO) COVID-19 adalah penyakit menular yang disebabkan oleh jenis coronavirus yang baru ditemukan dan pertama kali muncul di Wuhan, Tiongkok pada bulan Desember. Beberapa jenis coronavirus diketahui menyebabkan infeksi saluran pernapasan pada manusia mulai dari batuk hingga pilek sampai yang paling parah yaitu Middle East Respiratory Syndrome (MERS) dan Severe Acute Respiratory Syndrome (SARS) (Guan, dkk 2020). Wabah penyakit ini menyerang seluruh dunia terutama Indonesia juga terdampak virus ini. Wabah COVID-19 menyerang di berbagai sektor kehidupan masyarakat. Warga yang rentan terkena virus COVID-19 adalah yang memiliki riwayat penyakit, lansia dan juga bagi ibu hamil serta anak kecil dibawah umur 5tahun. Makalah New England Journal of Medicine hari kamis menganalisis "karakteristik 425 orang pertama di wuhan yang terinfeksi oleh virus yang dikenal sebagai 2019-nCov dan menemukan bahwa tidak ada yang 
lebih muda dari 15 rata-rata usia pasien adalah 59 tahun dan yang meninggal akibat penyakit itu berusia 36 tahun.”

Kuliah kerja nyata adala kegiatan internal yang dilaksanakan untuk mewujudkan tiga hukum perguruan tinggi (tri dharma perguruan tinggi) yaitu pendidikan, penelitian, dan pengabdian kepada masyarakat (Al Hakim, 2020). Menurut Pasal 20 ayat 2 Undang-Undang Republik Indonesia Nomor 20 Tahun 2003 tentang Sistem Pendidikan Nasional menyatakan : "Perguruan tinggi berkewajiban menyelenggarakan pendidikan, penelitian, dan pengabdian masyarakat". Tujuan dari adanya kegiatan KKN ini adalah untuk melatih mahasiswa menghadapi kehidupan nyata dimasyarakat baik bersosialisasi maupun dalam menghadapi permasalahan. Dengan adanya kegiatan KKN mendekatkan perguruan tinggi dan masyarakat sehingga eksistensi perguruan tinggi akan semakin dikenal di masyarakat karena telah melahirkan mahasiswa yang mampu ikut serta dalam kegiatan pembangunan dimasyarakat.

Dibidang kesehatan pemerintah telah dengan gencarnya mengedukasi masyarakat terkait pentingnya hidup bersih dan sehat, perlunya mengenakan masker saat diluar rumah, pelaksanaan karantina mandiri untuk orang-orang yang memiliki risiko tinggi, serta berbagai pedoman yang bertujan untuk mencegah penularan COVID-19 (Telaum banua, 2020). Pemerintah mengeluarkan himbauan untuk mematuhi protokol kesehatan yang telah ditetapkan guna untuk meminimalisir penyebaran virus. Dengan selalu mencuci tangan, menggunakan masker dengan benar, menggunakan handsanitizer dan menjaga jarak minimal 1 meter atau menjauhi kerumunan menjadi hal yang bisa dilakukan oleh masyarakat. Untuk hal termudah yang dapat dilakukan oleh masyarakat adalah menggunakan masker dan handsanitizer menjadi salah satu alternatif yang mudah untuk dilakukan setiap masyarakat agar terhindar dari virus COVID-19. Menggunakan masker yang benar dan selalu membawa handsanitizer selama berpergian dapat dengan mudah dilakukan seperti contohnya saja menggunakan masker ketika hendak berpergian baik dekat maupun jauh dan selalu sedia handsanitizer. Dalam mencegah penularan dan penyebaran COVID-19 ini, kami mengedukasi masyarakat melalui pemberian pemahaman tentang COVID-19 
pentingnya penggunaan masker saat berpergian, pentingnya memakai handsanitizer saar berada diluar rumah dan pentingnya mencuci tangan yang benar (Alan et al., 2020).

Dibidang sosial masyarakat pemerintah dengan gencar mencanangkan konsep mitigasi komunitas berupa pengurangan frekuensi pertemuan besar dan pembatasan jarak antar orang di fasilitas umum, hingga penerapan konsep aktivitas yang lebih baik dilaksanakan dirumah (Yunus,dkk 2020). Terkhusukan solo terkena dampak wabah COVID-19 hingga diberlakukannya KLB (Kejadian Luar Biasa) karena tidak adanya persiapan untuk segera menanggulangi orang yang terkena COVID-19 membuat solo korbannya menjadi membludak dan solo menjadi zona merah. Sehingga pemerintah menghimbau untuk tetap berada dirumah hingga melakukan segala aktivitasnya dirumah. Tidak ada wilayah di solo yang tidak terdampak virus ini.

Kelurahan Sumber Dukuhan RT 02 RW 09 Kecamatan Banjarsari, Surakarta merupakan salah satu dari 15 kelurahan yang ada di Kecamatan Banjarsari yang mana memiliki penduduk yang cukup banyak dan daerah yang sering dilalui banyak orang karena tempatnya yang cukup strategis berada dekat dengan jalan raya dan juga dengan jalan tol serta batas-batas kota. Hal ini menjadi salah satu penyebab rentannya daerah ini untuk penyebaran COVID-19 apabila tidak adanya pemahaman dan protokol kesehatan dalam penanggulangan COVID19( (Shodiqin, dkk 2020). Oleh karena itu, perlu adanya edukasi untuk meningkatkan pemahaman pada warga Sumber Dukuhan akan pentingnya mentaati protokol kesehatan yang ada.

Berdasarkan permasalahan diatas maka pengabdi tertarik untuk melaksanakan KKN dengan melakukan edukasi kepada masyarakat Sumber Dukuhan RT 02 RW 09 dalam mencegah penyebaran COVID-19. Dalam mencegah penyebaran COVID-19 diberikan edukasi mengenai pemahaman tentang COVID-19, pentingnya penggunaan masker saat berpergian, pentingnya menggunakan handsanitizer saat berada diluar rumah dan pentingnya mencuci tangan. 


\section{TINJAUAN PUSTAKA}

\section{Covid-19}

COVID-19 (coronavirus disease 2019) World Health Organization (WHO) mengumumkan nama penyakit ini sebagai Virus Corona Disease (Covid-19) yang disebabkan oleh virus SARS-CoV-2 yang sebelumnya disebut dengan 2019-n-CoV menginfeksi sistem pernapasan orang yang terjangkit yang dikenal dengan COVID-19 (Lai et al., 2020) dan dinyatakan sebagai pandemik pada tanggal 12 Maret 2020 (Susilo dkk., 2020). Corona Virus Dsease 2019 ini penyebarannya terjadi pada awalnya di kota Wuhan (Okada et al., 2020) COVID-19 ini menimbulkan gejala gangguan pernafasan akut seperti demam diatas $38^{\circ} \mathrm{C}$, batuk, penderita akan mengalami sesak nafas, dan untuk pasien yang memiliki riwayat penyakit berat akan menimbulkan kematian. Masa inkubasi covid-19 di untuk menyerang ditubuh manusia adalah 2-14hari. Penularan virus COVID-19 ini melalui kontak erat dan droplet yaitu dari percikan-percikan dari hidung dan mulut, kontak dengan droplet dan fekal-oral. Percikan-

percikan tersebut akan menempel pada benda dan orang bisa terinfeksi jika menyentuh benda tersebut. Virus ini dapat bertahan hingga 72 jam pada plastik dan stainless steel, kurang dari 24 jam pada karton dan kurang dari 4 jam pada tembaga (Chan et al., 2020; WHO, 2020). Berdasarkan penelitian yang dilakukan oleh Huang dkk. (2020), gejala klinis yang paling sering terjadi pada pasien Covid-19 yaitu demam (98\%), batuk (76\%), dan myalgia atau kelemahan (44\%). Gejala lain yang terdapat pada pasien, namun tidak begitu sering ditemukan yaitu produksi sputum (28\%), sakit kepala $8 \%$, batuk darah 5\%, dan diare $3 \%$. Sebanyak $55 \%$ dari pasien yang diteliti mengalami dispnea.

Penularan virus COVID-19 bisa terjadi ketika melakukan kontak langsung dengan orang yang terinfeksi terutama pada keluarga yang hidup serumah kemungkinan untuk terinfeksi sangat besar karena bersingungan langsung setiap hari termasuk memegang barang yang sama. Selain itu penularan virus ini bisa terjadi ketika imun seseorang sedang buruk atau sedang rendah dan melakukan berpergian baik jauh maupun dekat apalagi berpergian di daerah yang termasuk zona COVID-19. Orang yang rentan untuk terkena virus COVID-19 adalah lansia 
yang memiliki riwayat penyakit dan anak usia dibawah 15 tahun. Orang-orang dengan usia lanjut dan memiliki penyakt bawaan seperti diabetes dan hipertensi memiliki kemungkinan lebih besar resiko tinggi untuk terkena COVID-19 (WHO, 2020).

\section{Kuliah Kerja Nyata}

Kuliah Kerja Nyata (KKN) adalah bentuk kegiatan pengabdian kepada masyarakat oleh mahasiswa dengan pendekatan lintas keilmuan dan sektoral pada waktu dan daerah tertentu di Indonesia. KKN merupakan proses pengembangan di dalam pendidikan tinggi untuk mengasah dan membekali mahasiswa dalam kompetensi sosial. Kegiatan KKN mengharuskan mahasiswa untuk turun secara langsung ke masyarakat dalam maksud untuk menjadi bagian masyarakat, dan mencoba menerapkan ilmu pengetahuan dan pengalaman mahasiswa tersebut untuk memecahkan permasalahan-permasalahan yang dihadapi oleh masyarakat secara akademis (aristoteles et al., 2018). Pengabdian pada masyarakat merupakan suatu kegiatan yang bertujuan membantu masyarakat tertentu dalam beberapa aktivitas tanpa mengharapkan imbalan dalam bentuk apapun (Riduwan, 2016). KKN diarahkan untuk menjamin keterkaitan antara dunia akademikteoritik dan dunia empirik-praktis. Dengan demikian akan terjadi interaksi sinergis, saling menerima dan memberi, saling asah, asih dan asuh antara mahasiswa dan masyarakat (BP-KKN, 2016).

\section{METODOLOGI PENELITIAN}

Program KKN dilaksanakan oleh mahasiswa Universitas Sebelas Maret sebagaimana melaksanakann Tri Dharma Perguruan Tinggi degan pengabdian di masyarakat sebagai wujud pengimplementasian ilmu yang diperoleh ketika di bangku perkuliahan. Lokasi pelaksanaan KKN yaitu berada di Sumber Dukuhan RT 02 RW 09 Kelurahan Sumber Kecamatan Banjarsari, Surakarta. Sumber dukuhan adalah salah satu desa yang terletak di Kelurahan Sumber, Kecatan Banjarsari, Kota Surakarta, Provinsi Jawa Tengah. Dalam proses mendapatka rumusan masalah, metode yang digunakan adalah dengan mengamati segala kegiatan langsung kehidupadan masyarakat sumber dukuhan pada saat pandemi. Setelah itu dilakukan pendefinisian masalah dan muncul masalah serta solusisolusi untuk mengatasi permasalahan yang ada. Dengan dasar itu dapat dibuatlah 
program-program yang bisa dilaksanakan dan diarapkan kedepannya dapat memberikan dampak yang positif serta perubahan pada masyarakat yang ada di Sumber Dukuhan.

Kegiatan KKN ini dilakukan menggunakan metode kualitatif yaitu dengan melakukan wawancara kepada infroman yang berkompeten. Selanjutnya dilakukan kegiatan observasi secara langsung lalu dilkukan studi kepustakaan oleh penulis. Jika data terkumpul analisis data untuk dapat mengetahui peranan kegiatan KKN yang dapat dilaksanakan sesuai dengan program kerja yang disusun sehingga kegiatan pengabdian yang dilakukan melalui kegiatan KKN yang diublish dalam bentuk artikel.

Tabel 1.1 Kegiatan KKN

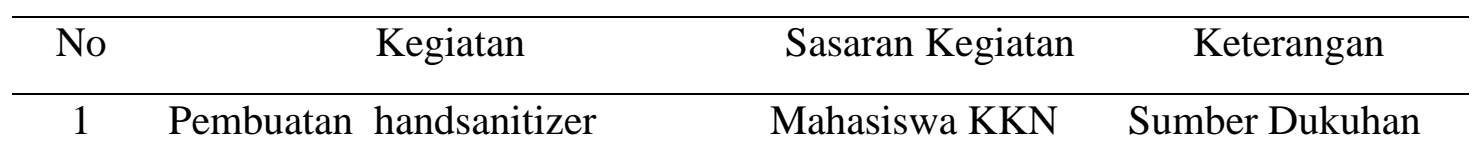

\begin{tabular}{|c|c|c|c|}
\hline 2 & $\begin{array}{lll}\text { Membagikan } & \text { Masker dan } \\
\text { Handsanitizer } & & \end{array}$ & $\begin{array}{l}\text { Ibu-ibu PKK } \\
\text { Sumber Dukuhan } \\
\text { RT 02 RW 09 }\end{array}$ & Rumah Mahasiswa \\
\hline 3 & $\begin{array}{l}\text { Memberikan edukasi mengenai } \\
\text { cara mencuci tangan dan } \\
\text { menggunakan masker yang baik } \\
\text { dan benar berupa penempelan } \\
\text { poster }\end{array}$ & \begin{tabular}{llr} 
Warga & \multicolumn{2}{l}{ Sumber } \\
Dukuhan & RT & 02 \\
RW 09 & &
\end{tabular} & Sumber Dukuhan \\
\hline 4 & $\begin{array}{l}\text { Memberikan edukasi mengenai } \\
\text { pola kehidupan yang sehat dan } \\
\text { new normal dan pemasangan } \\
\text { poster }\end{array}$ & $\begin{array}{l}\text { Warga Dukuhan } \\
\text { RT 02 RW } 09\end{array}$ & Sumber Dukuhan \\
\hline
\end{tabular}

\section{HASIL DAN PEMBAHASAN}

Program kuliah kerja nyata $(\mathrm{KKN})$ yang dilaksanakan di Sumber Dukuhan salah satunya yaitu memberikan edukasi mengenai pentingnya menaati protokol kesehatan. Sumber Dukuhan memilik banyak warga terutama yang sudah lanjut usia dan anak-anak kecil yang sangat rentan untuk terkena COVID-19, maka di perlukan perlindungan ekstra dari diri sendiri dan orang sekitar untuk memutus rantai penyebaran virus COVID-19 serta menerapkan pola hidup sehat. Program 
KKN dilakukan dengan menerapkan protokol pemerintah yaitu work from home dan social distancing (Nurhalimah 2020).

Program pertama yang dilakukan yaitu membuat handsanitizer dengan menggunakan bahan yang berada di rumah dan mudah untuk didapatkan, seperti alkohol dan juga gel aloe vera. Untuk pembuatan handsanitizer dilakukan sebagai berikut :

1. Sediakan peralatan dan bahan untuk membuat handsanitizer seperti Alkohol, Wadah Spray, Aloe vera.

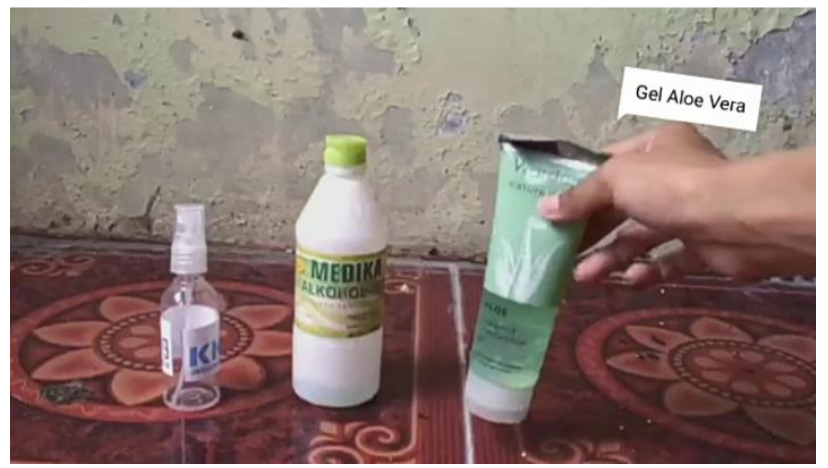

Gambar 1.1 Bahan pembuatan handsanitizer

2. Campur aloe vera dan alkohol di wadah dengan perbandingan 1:1 lalu di aduk hingga tercampur.

3. Setelah dirasa sudah tercampur tuangkan kedalam wadah spray.

4. Setelah handsanitizer jadi dimasukkan kedalam wadah kemas handsanitizer dan dikemas bersama dengan masker

5. Membagikan travel kit handsanitizer dan masker kepada warga sumber RT 02 RW 09 ketika membayar arisan RT.

Selain memberikan pengetahuan tentang pentingnya menggunakan masker yang baik dan benar, selain melakukan sosialisasi juga dilakukan pembuatan handsanitizer yang akan dibagikan kepada warga RT 02 RW 09, pembagian handsanitizer dan masker dilakukan pada saat ibu-ibu membayar arisan RT, karena pembagian dilakukan ketika pandemi sebagai simbolis masker dan handsanitizer diberikan kepada ibu RT 02 RW 09 dan ibu RW 09. 


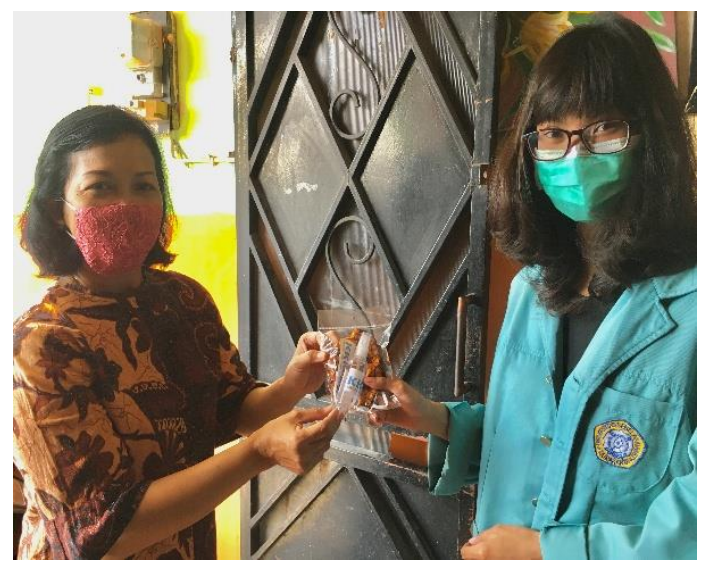

Gambar 1.2 Memberikan masker Bersama ibu RT 02 RW 09

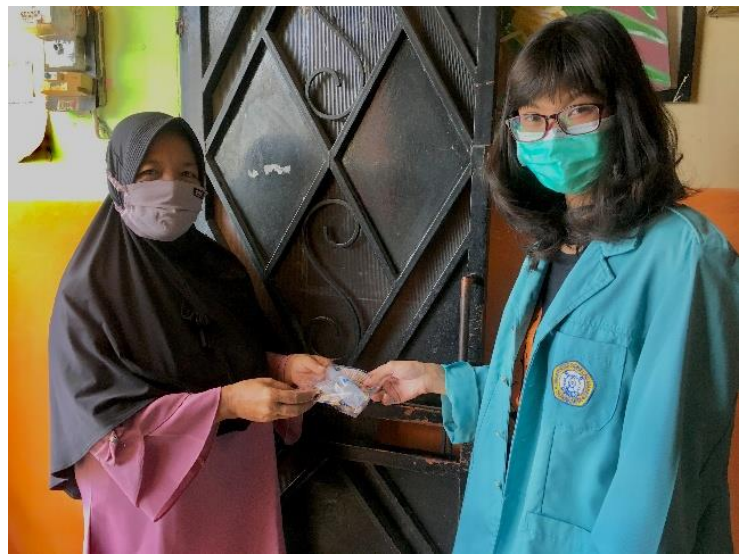

Gambar 1.3 Memberikan masker bersama ibu RW 09

Program edukasi menggunakan masker dengan benar dan menggunakan handsanitizer merupakan salah satu upaya untuk meminimalisir dan mencegah Virus COVID-19 semakin menyebar di RT 02 RW 09 Sumber Dukuhan. Kegiatan KKN COVID 19 dilakukan dengan membagikan masker dan handsanitizer kepada warga RT 02 RW 09 terutama pada saat perkumpulan arisan ibu-ibu PKK sembari diberikan edukasi tentang manfaat menggunakan masker dan handsanitizer untuk mencegah COVID-19.

Program kedua yang dilakukan yaitu pemasangan mmt di gapura jalan dibantu dengan bapak RT 02 RW 09 sebagai bentuk turut serta dari bapak RT kepada mahasiswa KKN karena ikut serta dalam meningkatkan kesadaran warga untuk waspada dengan virus COVID-19, dengan dipasangnya mmt di gapura jalan 
harapannya dengan pemasangan $\mathrm{mmt}$ bisa menjadi pengingat warga ketika melintas dan melihat mmt yang ada untuk selalu mematuhi protokol kesehatan, tidak hanya pemasangan mmt saja penulis juga melakukan pemasangan beberapa poster-poster tentang cara mencuci tangan, menggunakan masker yang benar, dan juga pola hidup sehat. Poster dibuat semenarik mungkin dengan memberikan gambar-gambar dan sedikit kata-kata agar warga tidak bosan melihatnya.

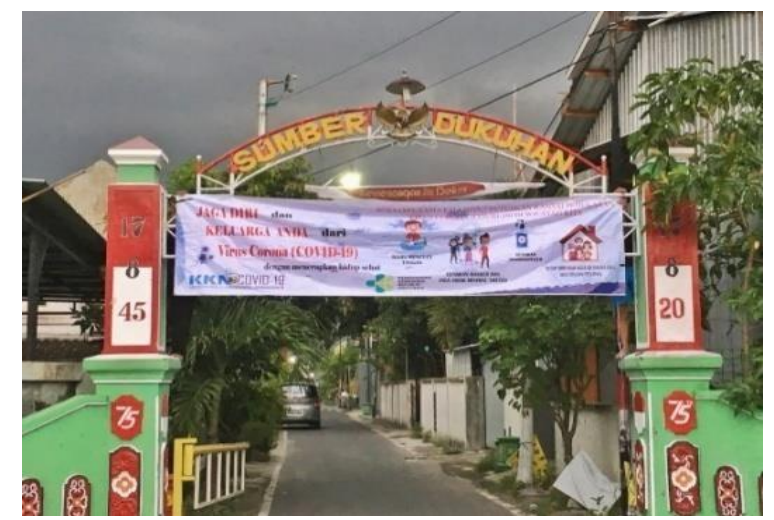

Gambar 1.4 Pemasangan mmt di gapura Jalan kahuripan RT 02 RW 09

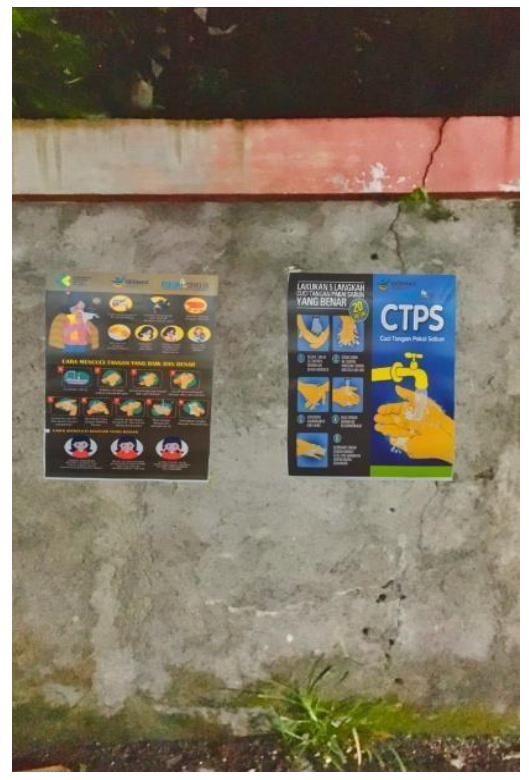

Gambar 1.5 Pemasangan poster

Program yang terakhir dilakukan yaitu melakukan pemasangan poster mengenai pola hidup sehat dan menjalankan new normal (pola kehidupan baru) new normal disini maksutnya adalah mulai membiasakan diri untuk hidup sehat dimulai dari selalu mencuci tangan sebelum melakukan kegiatan, selalu 
menggunakan masker, dan menjaga lingkungan sekitar agar tetap sehat. Kegiatan dilakukan dengan melakukan pemasangan poster di tembok pinggir jalan kahuripan RT 02 RW 09 yang dirasa strategis dan banyak orang melihat, penulis memilih penempelan dijalan ini karena jalan kahuripan merupakan jalan raya dan sering dilewati orang dari berbagai daerah sehingga nantinya tidak hanya warga sumber saja yang membaca tapi orang yang lewat bisa membaca.

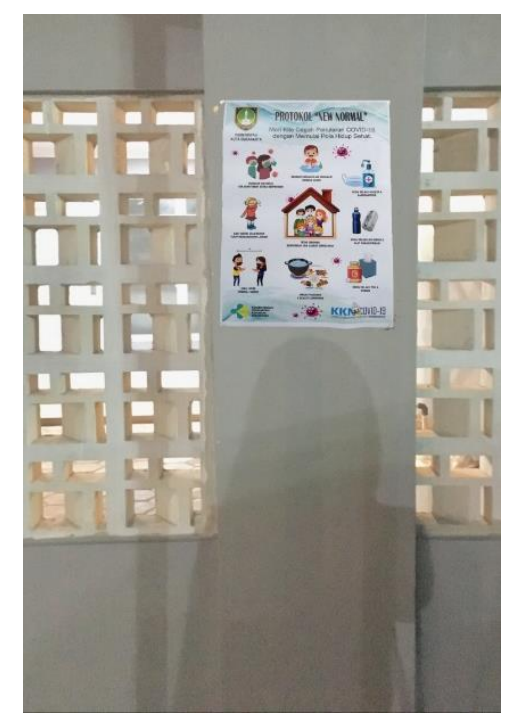

Gambar 1.6 Pemasangan poster new normal di jalan kahuripan RT 02 RW 09

\section{KESIMPULAN}

Berdasarkan kegiatan KKN COVID-19 yang dilakukan warga sumber RT 02 RW 09 memberikan respon yang baik dari awal perijinan kepada bapak RT 02 RW 09 memberikan tanggapan yang baik bila ada kegiatan KKN COVID-19 di daerahnya dan merasa terbantu untuk memberikan infromasi mengenai COVID19. Para warga sumber juga ikut turut serta mensukseskan kegiatan KKN COVID-19 ini, seperti pada saat pembagian masker dan handsanitizer, pemasangan mmt. Warga sumber merasa mendapat ilmu baru dan menambah pengetahuan tentang pentingnya mematuhi protokol kesehatan terutama untuk selalu menggunakan masker dan membawa handsanitizer ketika berpergian karena menyadari bahwa virus tidak hanya datang dari lingkungan sekitar atau keluarga tapi bisa juga datang ketika sedang berada dijalan bertemu dengan orang 
asing. Apalagi menjaga kesehatan diri sendiri sangatlah penting. Terlihat dengan adanya KKN COVID-19 yang telah dilakukan mengubah kebiasaan warga sumber menjadi lebih memperhatikan keadaan lingkungan sekitar dan semakin waspada dengan virus COVID-19. Dimana mulai ada perubahan baik di lingkungan sekitar maupun pada diri warga RT 02 RW 09. Mulai terlihat kesadaran dari warga untuk selalu mematuhi protokol kesehatan dari hal yang terkecil yaitu sudah tidak pernah terlihat kerumunan ibu-ibu atau bapak-bapak, ketika keluar rumah mulai memakai masker walaupun hanya ke rumah tetangga, anak kecil yang sedang bermain juga memakai masker, ditempat-tempat umum atau tepat makan selalu disediakan handsanitizer dan tempat mencuci tangan sehingga diwajibkan sebelum masuk dipastikan sudah mencucui tangan, cek suhu dan menggunakan handsanitizer Kegiatan edukasi dilakukan dengan tetap mematuhi protokol kesehatan yang diwajibkan. Dengan adanya program KKN COVID-19 ini diharapkan dapat meningkatkan pemahaman dan kesadaran warga RT 02 RW 09 akan pentingnya selalu mematuhi protokol kesehatan dan selalu menjaga kesehatan baik diri sendiri maupun lingkungan sekitar agar tetap terhindari dari COVID-19 lebih tepatnya meminimalisir virus COVID-19 menyebar.

\section{ACKNOWLEDGMENT}

Penulis mengucapkan terimakasih kepada Allah STW atas rahmat dan karunia-Nya. Terimakasih juga penulis ucapkan kepada UNS Surakarta dan LPPPM UNS selaku penyelenggara Kuliah Kerja Nyata (KKN) di tahun 2020. Untuk yang terakhir penulis ucapkan terimakasih yang sebesar-besarnya kepada Bapak Valiant Lukad Perdana Sutrisno, M.Pd selaku Dosen Pembimbing Lapangan KKN yang sudah sangat membantu dan membimbing selama kegiatan KKN serta masyarakat sumber dukuhan RT 02 RW 09 yang ikut serta melancarkan kegiatan KKN. 


\section{DAFTAR PUSTAKA}

Al Hakim, R. R. (2020). Pencegahan Penularan Covid-19 Berbasis Aplikasi Android Senagai Implementasi Kegiatan KKN Tematik Covid-19 di Sokanegara Purwokerto Banyumas. Community Engagement and $\begin{array}{llll}\text { Emergence } & \text { Journal } & \text { (CEEJ), } & \text { 2(1), }\end{array}$ https://doi.org/10.37385/ceej.v2i1.125

Aristoteles., Nur, E., Febi, E, F., Wisnu, L., Firmansyah. (2018). Sistem Informasi Kuliah Kerja Nyata $(\mathrm{KKN})$ Berbasis Android Universitas Lampung. Jurnal Komputasi Vol 6 No 2

BP-KKN. 2016. Petunjuk Teknik dan Petunjuk Pelaksanaan Kuliah Kerja Nyata (KKN) Tematik Universitas Lampung Periode Januari Tahun 2016. Lampung: Universitas

Chan, J. F., Yuan, S., Kok, K. H., To, K. H. K., Chu, H., Yang, J., ... \& Yuen, K. Y. (2020). A familial cluster of pneumonia associated with the 2019 novel coronavirus indicating person-to-person transmission: a study of a family cluster. The Lancet, 395(10223), 514-523. https://doi.org/10.1016/S0140$\underline{6736(20) 30154-9}$

Guan, W., Ni, Z., Hu, Y., Liang, W., Ou, C., He, J., ... Zhong, N. (2020). Clinical Characteristics of Coronavirus Disease 2019 in China. The New England Journal of Medicine, 382(18), 1708-1720. https://doi.org/10.1056/NEJMoa2 002032

Huang, C., Wang, Y., Li, X., Ren, L., Zhao, J., Hu, Y., ... Gu, X. (2020). Clinical Features of Patients Infected with 2019 Novel Coronavirus in Wuhan, China. Lancet, 395, 497-506. https://doi.org/10.1016/S0140$\underline{6736(20) 30183-5}$

Lai, C.-C., Shih, T.-P., Ko, W.-C., Tang, H.-J., \& Hsueh, P.-R. (2020). Severe acute respiratory syndrome coronavirus 2 (SARS-CoV-2) and corona virus disease-2019 (COVID-19): the epidemic and the challenges. International Journal of Antimicrobial Agents, 55(3), 105924.

Lampung.

Okada, P., Buathong, R., Phuygun, S., Thanadachakul, T., Parnmen, S., Wongboot, W.,..

Riduwan, a. 2016. "Pelaksanaan kegiatan pengabdian kepada masyarakat oleh perguruan tinggi”. researchgate. dikutip dari http://www.researchgate.net/publication/3137 
7846_pelaksanaan_kegiatan_pengabdian_kepada_masyarakat_oleh_perguru an tinggi. Diakses tanggal 16 Agustus 2020

Shodiqin, A., Aziz, R., Dewi, R., \&Fitriani, P. D. (2020) Model pemberdayaan jama'ah masjid menghadapi dampak coronavirus disease (covid 19).

Susilo, A., Rumende, C. M., Pitoyo, C.W., Santoso, W. D., Yulianti, M., Sinto, R., ... Yunihastuti, E. (2020). Coronavirus Disease 2019: Tinjauan Literatur Terkini. Jurnal Penyakit Dalam Indonesia, 7(1), 45-67.

Telaum banua, D. (2020). Urgensi Pembentukan AturanTerkaitPencegahan Covid-19 Di Indonesia. QALAMUNA: Jurnal Pendidikan, Sosial, dan Agama, 12(01), 59-70.

Vachiraphan, A. (2020). Early transmission patterns of coronavirus disease 2019 (COVID-19) in travellers from Wuhan to Thailand, January 2020. Eurosurveillance, 25(8), 2000097.

WHO. (2020) „WHO announces COVID-19 outbreak a pandemice World Health Organzation Regional Office for Europe. [online] Tersedia di: http://www.who.int/en/health-topics/health-emergencies/coronavirus-covid19/news/news/2020/3/who-announces-covid-19-outbreak-apandemicDiakses: 6 Mei 2020

World Health Organization. (2020). Coronavirus disease (COVID-2019) situation reports. New Delhi. SEARO 